\title{
Pembelajaran Blended Learning dengan Metode Praktikum untuk Meningkatkan Hasil Belajar Fisika Siswa SMK
}

\author{
H. Yunita*, F. Sesunan, H. Maulina, dan W. Suana \\ Program Studi Pendidikan Fisika, Fakultas Keguruan dan Ilmu Pendidikan, Universitas \\ Lampung, Indonesia \\ *Email: hermayunita66@gmail.com
}

Received: February 26 th 2021. Accepted: July 15th, 2021. Published: August 29th 2021

\begin{abstract}
Abstrak
Pandemi Covid-19 dan aturan pemerintah tentang Pemberlakuan Pembatasan Kegiatan Masyarakat di Indonesia menyebabkan kegiatan pembelajaran dengan tatap muka tidak dapat dilaksanakan secara penuh. Salah satu cara yang dapat dijadikan alternatif adalah melalui pembelajaran blended learning yang mengombinasikan kegiatan pembelajaran secara online dan offline. Penelitian ini bertujuan menguji peningkatan hasil belajar siswa SMK melalui pembelajaran blended learning dengan metode praktikum. Populasi penelitian ini adalah seluruh siswa kelas XI TKJ SMK Negeri 1 Liwa, dan sampel yang dipilih dengan teknik purposive sampling adalah siswa kelas X-TKJ1 sebagai kelas kontrol dan siswa kelas X-TKJ2 sebagai kelas eksperimen. Penelitian ini menggunakan pretest-posttest control group design. Kedua kelas sampel diberikan pretest dan posttest yang selanjutnya dianalisis untuk menentukan $\mathrm{N}$-gain masing-masing kelas. Hasil penelitian menunjukkan perbedaan hasil belajar siswa kelas eksperimen dan kontrol dengan $\mathrm{N}$-gain berturutturut, yaitu 0,72 dan 0,40. Hasil analisis tersebut menunjukkan rata-rata peningkatan hasil belajar siswa pada kelas eksperimen lebih tinggi dibandingkan dengan kelas kontrol. Berdasarkan hasil analisis data dapat disimpulkan bahwa pembelajaran blended learning dengan metode praktikum mampu meningkatkan hasil belajar siswa.
\end{abstract}




\begin{abstract}
The Covid-19 pandemic and government regulations regarding the Enforcement of Restrictions on Community Activities in Indonesia have caused face-to-face learning activities not to be fully implemented. One way to be used as an alternative is through blended learning, which combines online and offline learning activities. This study aims to test vocational students' learning outcomes through blended learning with practicum methods. The population of this study was all students of class XI TKJ of SMK Negeri 1 Liwa, and the samples selected by purposive sampling technique were students of class X-TKJ1 as the control class and students of X-TKJ2 as the experimental class. This study used a pretest-posttest control group design. The two sample classes were given a pretest and posttest, which were then analyzed to determine the $\mathrm{N}$-gain for each class. The results showed differences in student learning outcomes in the experimental and control classes with $\mathrm{N}$-gains, respectively, 0.72 and 0.40 . The analysis results showed that the average increase in student learning outcomes in the experimental class was higher than in the control class. Based on the results of data analysis, it can be concluded that blended learning with practicum methods can improve student learning outcomes.@2021PERJ
\end{abstract}

Keywords: Blended learning; practicum method; vocational students' learning outcomes.

\title{
PENDAHULUAN
}

Fisika merupakan bagian dari Ilmu Pengetahuan Alam (IPA) yang berkaitan dengan cara mencari tahu tentang fenomena alam yang dapat diamati serta dapat diukur secara sistematis untuk mendapatkan fakta menggunakan metode ilmiah (Marlina, 2020). Hal ini dapat diwujudkan salah satunya dengan menerapkan metode praktikum pada pembelajaran fisika (Adisendjaja, 2013; Gaffar, 2016; Ikhsaniati, 2013). Melalui praktikum, siswa dapat memperoleh pengalaman langsung untuk mengamati fenomena fisis yang terjadi, sehingga siswa lebih memahami konsep yang diajarkan (Fakhrrazie dan Fathony, 2016).

Pandemi Covid 19 yang melanda dunia saat ini berdampak pada larangan pembelajaran tatap muka, terutama untuk daerah zona merah. Oleh karena itu, guru harus mampu memilih strategi pembelajaran dalam menghadapi berbagai kendala akibat pembelajaran online. Lampung barat 
yang saat ini masih berada di zona hijau juga mengikuti aturan pemerintah untuk melaksakan pembelajaran online secara penuh, kecuali prakikum. Praktikum dapat dilakukan secara langsung dengan jumlah siswa yang terbatas dan mematuhi protokol kesehatan. Berdasarkan aturan tersebut, guru dapat mengoptimalkan pembelajaran fisika dengan menerapkan model pembelajaran blended learning menggunakan WhatssApp Group (online) dan kegiatan praktikum secara langsung.

Blended learning merupakan pembelajaran yang mengombinasi kegiatan tatap muka dan pembelajaran berbasis komputer, baik secara luar jaringan (offline), maupun dalam jaringan komputer (online) (Dwiyogo, 2018). Kelebihan penerapan blended learning antara lain: pembelajaran lebih efektif dan efisien, tidak terbatas ruang dan waktu, siswa dapat mengakses materi secara online, guru dan siswa dapat berdiskusi di luar jam tatap muka, serta hasil belajar lebih optimal (Husamah, 2014; Nastiti, 2016; Carman, 2013). Selain itu, menurut Aunillah (2018), pembelajaran blended learning dengan pendekatan ilmiah dapat meningkatkan hasil belajar kognitif siswa. Khoiroh (2017) melalui hasil penelitiannya juga menemukan bahwa pembelajaran blended learning berpengaruh secara signifikan terhadap hasil belajar siswa.

Berdasarkan hasil wawancara terhadap guru fisika SMKN 1 Liwa diperoleh data bahwa pembelajaran berbasis praktikum sangat jarang dilakukan. Praktikum paling banyak dilakukan satu kali selama satu tahun, sementara di dalam fisika terdapat tuntutan pembelajaran praktikum pada Kompetensi Dasar 4. Metode praktikum dipilih karena siswa dapat memeroleh pengalaman langsung dalam menemukan konsep sehingga diharapkan pengetahuan yang diperoleh akan lebih bermakna (Akkoyunlu \& Soylu, 2006).

Berdasarkan hasil angket yang diberikan kepada siswa jurusan TKJ diperoleh data sebesar $40 \%$ siswa mengalami kesulitan dalam mempelajari materi Hukum Kirchoff, 54\% menyatakan cukup sulit, dan 6\% menyatakan tidak mengalami kesulitan. Materi Hukum Kirchoff tentang listrik dianggap paling sulit bagi siswa dan perolehan hasil belajar yang rendah, yaitu hanya 10 siswa yang mampu lulus KKM dari 30 siswa pada satu kelas. Hal ini menunjukkan bahwa materi Hukum Kirchoff perlu penanganan agar hasil belajar siswa menjadi lebih baik.

Hingga saat ini, belum terdapat penelitian tentang pembelajaran blended learning dengan metode praktikum, khususnya untuk siswa SMK. Berdasarkan analisis masalah dan analisis kebutuhan yang telah dilakukan, perlu dilakukan penelitian tentang pembelajaran blended learning dengan metode praktikum untuk meningkatkan 
hasil belajar siswa, khususnya pada materi Hukum Kirchoff. Blended learning dengan metode praktikum dapat membantu siswa untuk membuat trobosan-trobosan baru melalui penemuan dari hasil percobaan dan membuat siswa lebih percaya tentang kebenaran suatu materi, serta membuat simpulan berdasarkan percobaan (Pratiwi \& Herlia, 2019).

\section{METODE}

Penelitian ini merupakan penelitian eksperimen. Subjek penelitian diambil menggunakan teknik purposive sampling dengan mengambil dua kelas, satu kelas digunakan sebagai kelas eksperimen dan satu kelas sebagai kelas kontrol. Desain penelitian menggunakan Pretest-Posstest Control Group Design. Prosedur penelitian ini meliputi tahap persiapan, tahap pelaksanaan dan tahap refleksi hingga evaluasi.

Sebelum digunakan, soal tes (pretest dan posttest) diuji validitas dan reliabilitas terlebih dahulu untuk mengetahui kelayakan instrumen. Pengujian dilakukan di luar sampel penelitian. Uji instrumen dilakukan terhadap siswa kelas XI TKJ SMK Negeri 1 Liwa yang telah belajar mengenai hukum kirchoff dengan jumlah soal kognitif sebanyak 14 butir soal. Hasil analisis uji coba menggunakan SPSS versi 21.0 menunjukkan bahwa instrumen yang digunakan valid dan reliabel.
Analisis data penelitian menggunakan uji homogenitas, normalitas, dan uji gain untuk menentukan peningkatan hasil belajar siswa. Analisis data dilakukan menggunakan alat bantu SPSS versi 21.0.

\section{HASIL DAN PEMBAHASAN}

Pembelajaran blended learning menggunakan metode praktikum dilakukan untuk meningkatkan hasil belajar siswa. Pengujian dilakukan dengan membandingkan dua kelas sampel, yaitu kelas eksperimen dan kontrol. Kedua kelas diuji homogenitas sebelum diberi perlakuan. Berdasarkan hasil pengujian homogenitas, diketahui nilai sig. 0, $889(>0,05)$ sehingga dapat disimpulkan bahwa kedua kelas mempunyai varian yang sama (homogen).

Kedua kelas juga diuji normalitas untuk mengetahui sebaran data penelitian. Hasil uji normalitas menunjukkan bahwa data terdistribusi normal dengan nilai Asymp. Sig $>0,050$ yaitu sebesar 0,81 pada kelas eksperimen dan 0,40 pada kelas kontrol.

Hasil belajar kognitif siswa diperoleh dari nilai pretest dan postest siswa. Hasil tersebut menunjukan bahwa nilai rata-rata kelas eksperimen (baik pada pretest maupun posttest) lebih tinggi dibanding kelas kontrol. Rekapitulasi hasil belajar siswa disajikan pada Tabel 1.

Kelas eksperimen dan kontrol 
diberikan 10 butir soal kognitif pada pretest dan posttest. Pertemuan pertama dilakukan pretest dan pertemuan ke empat dilakukan posttest dengan level soal kognitif C1-C6. Peningkatan hasil belajar kongnitif kelas eksperimen dan kelas kontrol dilihat berdasarkan nilai $\mathrm{N}$-gain kelas eksperimen sebesar 0,72 dengan ketogeri tinggi dan kelas kontrol 0,40 dengan kategori sedang . Berdasarkan hasil tersebut, peningkatan hasil belajar kognitif kelas eksperimen lebih tinggi dibanding kelas kontrol. Hal ini sesuai dengan penilitian yang dilakukan oleh Hayat et al. (2011) dan Rachman et al. (2019) bahwa peningkatan hasil belajar siswa menggunakan blended learning lebih tinggi dibanding kelas online.

Tabel 1. Rekapitulasi Hasil Belajar Sisiwa

\begin{tabular}{lcccc}
\hline \multirow{2}{*}{ Parameter } & \multicolumn{2}{c}{ Pretest } & \multicolumn{2}{c}{ Posttest } \\
\cline { 2 - 5 } & Eksperimen & Kontrol & Eksperimen & Kontrol \\
\hline Jumlah siswa & 30 & 30 & 30 & 30 \\
Nilai terendah & 20,00 & 10,00 & 70,00 & 40,00 \\
Nilai tertinggi & 60,00 & 50,00 & 100,00 & 70,00 \\
Nilai maksimum & 100,00 & 100,00 & 100,00 & 100,00 \\
Rata-rata nilai & 26,00 & 24,33 & 86,33 & 55,66 \\
\hline
\end{tabular}

Model pembelajaran blended learning dengan metode praktikum berpengaruh terhadap hasil belajar karena pada proses pembelajaran siswa memiliki waktu yang lebih panjang untuk belajar, tidak hanya di dalam kelas tetapi juga di luar kleas (Ekawati, 2018; Niarsi et al., 2019). Selain itu, siswa juga dapat berinteraksi dengan guru di luar kelas melalaui WhatsApp dan siswa melakukan eksperimen secara langsung sehingga mampu meningkatkan pemahaman konsep dan hasil belajar (Asalla, 2010).

Berdasarkan hasil wawancara, siswa menyatakan bahwa dengan blended learning, pembelajaran menjadi tidak terkesan monoton. Siswa juga merasa lebih nyaman karena tidak harus mencatat semua materi yang disampaikan. Siswa dapat mendownload materi yang disampaikan di google classroom yang telah disediakan (Alfath et al., 2013). Pembelajaran blended learning dengan metode praktikum dapat mengatasi rasa bosan yang dialami siswa selama pembelajaran. Hal ini menjadi salah satu faktor meningkatnya hasil belajar siswa karena siswa lebih menikmati dan fokus dalam pembelajaran yang berlangsung (Pradipta et al., 2020).

\section{KESIMPULAN}

Berdasarkan hasil analisis data penelitian, diperoleh kesimpulan bahwa model pembelajaran blended learning dengan metode praktikum 
dapat meningkatkan hasil belajar fisika siswa SMK Negeri 1 Liwa. Peningkatan hasil belajar tersebut terlihat dari koefisien $\mathrm{N}$-gain kelas eksperimen dan kontrol masingmasing sebesar 0,72 (kategori tinggi) dan 0,40 ( kategori sedang).

\section{DAFTAR PUSTAKA}

Adisendjaja, Y. H. (2013). Kegiatan Praktikum Dalam Pendidikan Sains. Surabaya: Usaha Nasional.

Akkoyunlu, B, \& Soylu, M. (2006). A Study on Students Views on Blended Learning Environment Faculty of Education Department of Computer Education and Instructional Technology. Turkish Online Journal of Distance Education - TOJDE, 3 (3): 1302-6488.

Alfath, S. N., Ellianawati, \& Sukisno, M. (2013). Pengembangan Media Blended Learning Berbasis Web. Unnes Physics Education Journal, 2(1), 1-6. http://journal.unnes.ac.id/s ju/index.php/upej

Asalla, L. K. (2010). Meningkatkan Kualitas Blended Learning: Case Study Menggunakan CoI Model. ComTech: Computer, Mathematics and Engineering Applications, 1(2), 770.

Aunillah, T. N. (2018). Efektifitas Blended Learning Pada Materi
Fluida Dinamis Terhadap Hasil Belajar Siswa. Pendidikan Matematika dan Ilmu Pengetahuan Alam, hlm. 1-67.

Carman, J. (2013). Blended Learning Design: Five Key Ingredients. Learning Technical Report.

Dwiyogo,

W.D.

(2018).

Pembelajaran Berbasis Blended Learning. Depok: Raja Grafindo. Ekawati, N. E. (2018). Penerapan Blended Learning dengan Aplikasi Edmodo Berbasis Strategi Pembelajaran PDEODE untuk Meningkatkan Prestasi Belajar Siswa. Jurnal Ilmiah Pendidikan MIPA. 8(1): 7-16.

Fakhrrazie dan Fathony. (2016). Pengaruh Pembelajaran Metode Praktikum pada Materi Laju Reaksi Terhadap Hasil Belajar Siswa MAN. Jurnal Pendidikan dan Pembelajaran Khatulistiwa, 5 (3).

Gaffar, A. (2016). Pembelajaran Berbasis Praktikum Virtual Untuk Meningkatkan Sikap Ilmiah Siswa Kelas X Pada Materi Invertebrata. Bio Educatio, 1(1), 18-25.

Hayat, M.S, Anggraeni, S., dan Redjeki, S. (2011). Pembelajaran Berbasis Praktikum Pada Konsep Invertebrata untuk Pengembangan Sikap Ilmiah Siswa. Http:/ / Isjd.Pdii.Lipi.Go.Id/Ad min/Jurnal/1211141152_20865481.Pdf. 
Husamah. 2014. Pembelajaran Bauran (Blended Learning). Jakarta: Prestasi Pustaka Raya. Ikhsaniati, Rakhmi Nur. 2013. Pengaruh Pembelajaran Berbasis Praktikum Terhadap Kemampuan Berpikir Kritis dan Penguasaan Konsep Siswa. Tesis. Universitas Negeri Semarang, pp. 25-29

Khoiroh, dkk. (2017). Pengaruh Penggunaan Media StatisDinamis pada Sistem Reproduksi Manusia terhadap Penguasaan Konsep Siswa. Proceeding Biology Education Conference, 14 (1). 449-454.

Marlina, E. (2020). Pengembangan Model Pembelajaran Blended Learning berbantuan Aplikasi Sevima Edlink. Jurnal Padegogik, 3(2), 104-110.

Nastiti, D. W. (2016). Pengaruh Pembelajaran Bauran (Blended Learning) Terhadap Motivasi dan Hasil Belajar Siswa Pada Materi Relasi dan Fungsi. Fakultas Keguruan dan Ilmu Pendidikan, Universitas Nusantara PGRI Kediri.

Niarsi, Cahyono, E., \& Supranowo. 2019. Analisis Hasil Belajar dan
Kemandirian Siswa pada

Pembelajaran Asam Basa dengan Metode Blended Learning. Jurnal Inovasi Pendidikan Kimia, 13(2): 24472459.

Pradipta, I. A., Chavidowaty, I. D., Hermawan, R., \& Kharisma, H. (2020). Implikasi Penerapan Blended Learning Selama Covid - 19 untuk Mata Pelajaran Simulasi Digital Kelas X SMK. Edudikara: Jurnal Pendidikan Dan Pembelajaran, 5(4), 207.

Pratiwi, A. (2019). Pengaruh Blended Learning Berbantuan Google Classroom Terhadap Hasil Belajar Siswa SMA Pada Konsep Gerak Lurus. Fakultas Ilmu Tarbiyah dan Keguruan, Yogyakarta: UIN Sunan Kalijaga Yogyakarta.

Rachman, A. dan Yusep, S. (2019). Penerapan Model Blended Learning dalam Peningkatan Hasil Belajar Menggambar Objek 2 Dimensi. Journal of Mechanical Engineering Education, 6(2), 145-152. https://doi.org/10.17509/jmee .v6i2.21784 
Phy. Educ. Res. J. Vol. 3 No. 2 (2021), 133-140 